DOI: 10.12731/2227-930X-2018-4-74-98

УДК 37.014

\title{
ИДЕОЛОГО-ОБРАЗОВАТЕЛЬНАЯ ЛОГИСТИКА ВО ВНЕШНЕЙ И ВНУТРЕННЕЙ ГОСУДАРСТЕННО-ОБРАЗОВАТЕЛЬНОЙ ПОЛИТИКЕ ВЫСШЕГО ОБРАЗОВАНИЯ И ПОЛИТИКЕ МЯГКОЙ СИЛЫ ФРГ И ФРАНЦУЗСКОЙ РЕСПУБЛИКИ
}

\section{Житнов Е.А.}

В статье были рассмотрены системы выстего образования ФРГ и Франщии, основные направления реформирования систем выстего образования Франции и ФРГ в рамках создания общеевропейской образовательной системы. Статья позволила определить основные направления государственно-национальных особенностей образовательных систем этих двух стран. Перечислены преимущества и недостатки унификации образовательной деятельности; проведена оценка образовательного потенцииала Франции и Германии с помощью модели ИОЛ; определено рейтинговое положение этих стран среди наиболее успешных государств в образовательной сфере; показана роль образования Франциии и Германии в политике мягкой сильл.

Целью исследования является анализ основных факторов, влияющих на образовательную политику Франщузской Республики и ФРГ, выраженной в структурных оценках политики мягкой силь.

\section{Задачи исследования:}

- определить и исследовать основные закономерности, позволяющие выявить условия расширения системы национального образования Франиузской Республики и ФРГ на другие регионы мира;

- исследовать исторический путь развития системы национальных систем образования Франиузской Республики и ФРГ;

- качественно характеризовать степень конкурентоспособности образовательных систем Франиузской Республики и ФРГ; 
- конкретизировать иченностные ориентиры национальных образовательных систем, влияюшчх на формирование политики мягкой силь в ЕС.

- разработать методологические основы концепции по оценке государственно-образовательной политики, основанной на количественно-качественной модели идеолого-образовательной логистики, по оценке индекса развития образования.

Объект исследования - система государственно-образовательной политики Франиузской Республики и ФРГ.

Предмет исследования - факторы, структуры, системьл, модели и основные направления трансформации образовательной политики, выражаемые в политике мягкой силь и распространением ее на другие регионы мира, реализуемые Франиузской Республикой и ФРГ.

Результатыл. Результаты работы заключаются в том, что автор сделал попьттку создать интегральную модель оценки уровня развития государства, основанной на широком диапазоне различных информативных данных, включающчх различные показатели.

Область применения результатов. Результаты исследования могут быть использованы в педагогической, экономической, политической деятельностях, где требуется оценить уровень развития государства как в отдельном, так и интегральных аспектах.

Ключевые слова: высиее образование; ФРГ; Француия; идеологообразовательная логистика; Болонский прочесс; мягкая сила; квалиметрия; образование; политика; экономика; индексы.

\section{IDEOLOGICAL AND EDUCATIONAL LOGISTICS IN THE EXTERNAL AND INTERNAL STATE-EDUCATIONAL POLICY OF HIGHER EDUCATION AND THE SOFT FORCES POLITICS OF THE FEDERAL REPUBLIC OF GERMANY AND THE FRENCH REPUBLIC}

\section{Zhitnov E.A.}

The article considers the systems of higher education of Germany and France, also the article considers a main directions of reforming 
the higher education systems of the France and Germany in the framework of the creation of a pan-European educational system. The main directions of the state-national features of the educational systems of these two countries was determined. The article lists the advantages and disadvantages of the unification of educational activities; educational potential of the France and Germany was determined by the methodology of ideology-educational logistics; the rating position of these countries was determined among successful States in the sphere of education; we determined the role of education in the France and Germany in the soft power policy.

The purpose of the research is the analyze of the main factors of influencing the educational policy of the France and Germany. Which is expressed in structural assessments of soft power politics.

\section{Tasks of the study:}

- to define and to study the basic of basics of the development of the national education of the France and Germany. Which expands the influence on other countries;

- to study the historical path of development of the system of national education France and Germany;

- to characterize the degree of competitiveness of the educational system of the France and Germany;

- to develop the methodological bases of the concept of the evaluation of state-educational policy. Which is based by the quantitative and the qualitative model of ideological and educational logistics, according to the evaluation of the education development index.

The object of the study is the system of the state of the educational policy of the France and Germany.

The subject of the study is the research are factors, structures, systems, models and main directions of the transformation of educational policy. Which are expressed by the policy of soft power and it spreads on other regions of the world is implemented by the France and Germany.

Methodology in article scientific abstraction, classification, comparison, as well as concepts and principles of innovation management, methods of comparative analysis, methods of peer review were used. 
The results. The results of the work are about making an attempt to create an integral model of assessing the state development level based on a wide range of various informative data, including different indicators.

Practical implications. The results of the research can be used in pedagogical, economic, political practices where it is required to assess the level of state development both in a separate and integral aspects.

Keywords: higher education; Germany; France; ideological educational logistics; Bologna process; soft power; qualimetry; education; politics; economy; indices.

\section{Введение}

Образовательная политика любого государства практически всегда стоит на передовых позициях, внесенных в повестку дня правительствами стран, являясь неотъемлемой частью всего международного сообщества. Систему высшего профессионального образования можно характеризовать как форму правового регулирования, относящуюся к международному публичному праву, т.к. правительствами стран постоянно заключаются международные договоры (Болонский процесс, ВТО (Генеральное соглашение по торговле услугами (ГАТС) и Соглашение по торговым аспектам прав интеллектуальной собственности (ТРИПС)), Всемирная организация интеллектуальной собственности ВОИС) с целью повысить систему внешнего контроля над этой отраслью и достичь особых государственных задач.

Взаимодействие по межгосударственным договорам привело к возрастанию конкуренции среди образовательных систем различных стран. В центре внимания всегда оказывались государства, относящиеся к западному миру. Если рассматривать Европейский Союз, который имеет особую цель политического и экономического объединения государств Европейского контингента, то основная форма данного объединения выражается в унификации правового поля по разным аспектам (включающим и образовательный сектор). Стандартизирование правового поля всех стран участников ЕС по- 
зволило создать единый рынок, позволяющий беспрепятственно перемещаться гражданам внутри ЕС, это касается также товаров, капитала и услуг. Данный правовой подход ЕС позволил гражданам любой страны члена Союза беспрепятственно работать и проживать в другом государстве члена Европейского Объединения. Если убрать из правового внимания то, что ЕС является международной организацией, но это объединение обладает всеми признаками государства, т.к. имеет целую структуру, выражаемую в наднациональных институтах Европейского совета, Европейской комиссии, Совете Европейского союза, Суда Европейского союза, Европейской счётной палате, Европейского центрального банка и Европейского парламента. Но даже с учетом того, что с одной стороны существует мощный наднациональный орган, который должен принимать централизованные решения, исходящие от единой позиции всех стран членов ЕС, в данном объединении существуют два государства (Beликобританию мы не рассматриваем, т.к. в 2016 г. граждане на референдуме высказались за выход из ЕС), которые по тем или иным историческим причинам являются центром принятия стратегических решений как во внутренний, так и внешней политике Союза. К таким государствам относятся: Французская Республика и Федеративная Республика Германия. Условно эти государства входят в так называемый клуб государств, именуемых «великими державами» [2]. Французская Республика по своему внешнеполитическому влиянию стоит выше ФРГ ввиду того, что Франция обладает ядерным арсеналом и является постоянным членом ООН с правом вето. Но если рассматривать эти государства в сравнительно-аналитическом аспекте, то можно отметить, что более сбалансированная экономическая политика осуществляется именно в ФРГ (Таблица 3) [11].

Таким образом, отмечая то, что Франция и ФРГ хоть и являются неотъемлемой частью ЕС с имеющимся там мощным наднациональным органом, внутренняя образовательная политика каждого государства остается под управлением своих национальных законодательных и исполнительных институтов власти ввиду особого внутреннего самосознания личной исторической, культурной, 
языковой, религиозной и др. идентичности. Любую политику, осуществляемую в системе высшего образования тем или иным национальным правительством, можно считать формой стабилизации или повышения эффективности экономической ситуации в государстве путем создания среды по подготовке высококвалифицированных кадров в тех отраслях, в которых нуждается экономика. Несбалансированная подготовка кадров или наличие вузов, которые не способны формировать необходимый набор компетенций у выпускников, приводит к ухудшению экономической безопасности государства, что в долгосрочной перспективе становится отрицательным фактором дальнейшего развития государства. Если исключить то, что управление системой высшего образования является основным фактором развития экономической стабильности государства, то можно заметить, как определенные правительства используют ее в продвижение своих определенных национальных интересов, идей и ценностей за рубеж. В работе Шпаковской Л.Л. [9] отмечается, что политика высшего образования включает в себя: систему, по которым функционируют вузы, количество функционирующих вузов, органы управления вузами, другие участники и организации, влияющие на функционирование вузов, а также те или иные правила, по которым регулируется кооперация.

Таблица 1.

Общие характеристики государства

\begin{tabular}{|c|l|l|l|}
\hline 1 & \multicolumn{1}{|c|}{ Позиция } & \multicolumn{1}{c|}{ Германия } & \multicolumn{1}{c|}{ Франция } \\
\hline 2 & Популяция & $80,594,017$ & $67,106,161$ \\
\hline 3 & Территория & 357,022 км. кв. & 643,801 км. кв. \\
\hline 4 & Возрастная структура & $0-14$ лет $-12.82 \%$ & $0-14$ лет $-18.53 \%$ \\
& & $15-24$ лет $-10.09 \%$ & $15-24$ лет $-11.79 \%$ \\
& & $25-54$ лет $-40.45 \%$ & $25-54$ лет $-37.78 \%$ \\
& & $55-64$ лет $-14.58 \%$ & $55-64$ лет $-12.42 \%$ \\
& & 65 лет и старше - & 65 лет и старше- \\
& & $22.06 \%$ & $19.48 \%$ \\
\hline 5 & Прирост населения: & $-0,16 \%(2017)$ & $0,39 \%$ (2017) \\
\hline 6 & Доля городского населения: & $75,7 \%$ & $80 \%$ \\
\hline 7 & Распространение националь- & & \\
& ного языка в других странах & & \\
\hline
\end{tabular}


Окончание табл. 1.

\begin{tabular}{|c|c|c|c|}
\hline 8 & $\begin{array}{l}\text { Ожидаемая продолжитель- } \\
\text { ность жизни: }\end{array}$ & 80,8 лет & 81,9 лет \\
\hline 9 & $\begin{array}{l}\text { Безработица среди моло- } \\
\text { дого населения 15-24 лет: }\end{array}$ & $\begin{array}{l}\text { Мужчины: 7,9\% } \\
\text { Женщины: 6,5\% }\end{array}$ & $\begin{array}{l}\text { Мужчины: 25\% } \\
\text { Женщины: } 24 \%\end{array}$ \\
\hline 10 & Затраты на образование: & $4,9 \%$ от ВВП (2013) & $5,5 \%$ от ВВП (2013) \\
\hline 11 & $\begin{array}{l}\text { Предположительный срок } \\
\text { обучения школа + вуз: }\end{array}$ & 17 лет & 16,5 лет \\
\hline 12 & $\begin{array}{l}\text { ВВП (паритет покупатель- } \\
\text { ной способности): }\end{array}$ & $\begin{array}{l}\$ 4,15 \text { триллиона } \\
(2017)\end{array}$ & $\begin{array}{l}\text { \$2,826 триллиона } \\
\text { (2017) }\end{array}$ \\
\hline 13 & $\begin{array}{l}\text { Темпы реального роста } \\
\text { ВВП: }\end{array}$ & $2,1 \%(2017)$ & $1,6 \%(2017)$ \\
\hline 14 & ВВП на душу населения: & $\$ 50,200(2017)$ & $\$ 43,600(2017)$ \\
\hline 15 & $\begin{array}{l}\text { Структура ВВП по секто- } \\
\text { рам (2017): }\end{array}$ & $\begin{array}{l}\text { сельское хозяйство: } \\
0,6 \% \\
\text { промышленность: } \\
30,1 \% \\
\text { услуг: } 69,3 \%\end{array}$ & $\begin{array}{l}\text { сельское хозяйство: } \\
1,6 \% \\
\text { промышленность: } \\
19,4 \% \\
\text { услуг: 78,9\% }\end{array}$ \\
\hline 16 & Государственный долг: & 65,7\% ВВП (2017). & 96,4\% ВВП (2017). \\
\hline
\end{tabular}

В данной работе мы сделаем акцент на исследование специфик образовательных политик Французской и ФРГ. Первоначально хотелось бы проанализировать систему государственно-образовательной политики Германии ввиду тог, что это:

1. ведущая экономика ЕC;

2. характер преобразований, который был преодолен Германией за последние десятилетия огромен;

3. ФРГ является страной, которая одна из первых (1998 г.) предложила создать унифицированное образовательное законодательство.

Отмечая особый интерес в идеолого-образовательном плане, можно без сомнения провести прямую параллель с системой образования РФ. Современную историю Германии можно разделить на периоды до и после падения (1989 г.) Берлинской Стены, которая разделила государство на ФРГ и ГДР. Первое включало в себя капиталистическую модель развития государства по западному образцу, второе содержало идеологические взгляды развития по социалистическому принципу, ориентированному на Советскую модель развития. Таким образом, нынешняя модель развития ФРГ, 
как и в РФ, имеет опыт развития по нескольким направлениям. Система образования в Германии всегда имела мощную поддержку со стороны государства, но начавшиеся проводимые реформы в 1970-х годах, положившие начало развитию рыночной экономики, заменили прямое управление финансированием образования на нецентрализованное, в которое был включен источник из частного сектора.

В период с 1999/2000 учебного года правительство ФРГ запустило поэтапный переход на новые платформы образовательных программ, тем самым был положен путь по разделению на различные виды и квалификации выдаваемых дипломов (бакалавр и магистр). Это включило постепенное расширение числа специальностей, а вузам был предоставлен самостоятельный выбор сроков и масштабов проведения реформ. Управленческие команды вузов и представители кругов бизнеса очень сдержанно реагировали на проведение реформ, имея скрытые опасения того, что новации могут негативно сказаться на качестве реализуемых программ, следовательно, это может напрямую отразиться на качестве подготовки нового поколения специалистов.

Существующая система высшего образования ФРГ характеризуется как тройная, ввиду исторического влияния капиталистической и социалистической идеологических систем, а также современного развития в структурах глобализма, когда были стерты границы в рамках образования ЕС. Все это позволило образовательной системе Германии отсечь все лишнее, аккумулировать и адаптировать все лучшее в формировании собственной национальной образовательной идентичности. Данный подход обусловлен тем, что любое государство должно стремиться к тому, что ее образовательная политика должна отвечать только собственным национальным целям и идеям.

Процесс зачисления в вузы осуществляется по окончании 13 -летнего школьного образования, где от абитуриентов требуется успешно сдать выпускные экзамены за весь период обучения в системе среднего образования, после чего выпускники получают 
документ, именуемый Abitur. Претенденты на зачисление в вузы как правило отбираются Центральным агентством по приему на уровень высшего профессионального образования по среднему балу полученных по окончании в школе сертификатов. В системе высшего образования ФРГ отмечается тот факт, что решение в определении порядка зачисления для потенциальных абитуриентов принимается непосредственно вузом. Но хотелось бы отметить тот факт, что кол-во зачисляемых выпускников школ на обучение на уровень высшего профессионального образования определяется централизованной политикой ФРГ.

Образовательно-университетский период обучения в вузах ФРГ для выпускников школ варьируется от 4,5-6 лет. Классические университеты придерживаются строгой образовательной политики, что процесс обучения должен состоять из 6 лет обучения, а для вузов с прикладными науками 4,5 года. По окончании вуза выпускнику присуждается одна из трех видов степеней, существующих в системе образования ФРГ:

1. в области естественных, общественных и инженерных наук в ФРГ выдается диплом, являющийся профессионально ориентированной степенью;

2. академические степени со степенью магистр присуждаются по завершении обучения на факультетах с гуманитарно-ориентированным содержанием;

3. выпускники, закончившие педагогические, медицинские и юридические вузы, получают статус государственных служащих.

Выпускникам, освоившим программы прикладных дисциплин, выдается диплом, в котором имеется пометка «FH» (Fachhochschulen), с целью отделить от университетского диплома. Студентам, прошедшим курс академии высшей профессиональной подготовки, выдается диплом, в котором имеется отметка ««Berufsacademia». В большинстве случаев финансирование в системе вузов имеет централизованную поддержку из федерального бюджета, но в определенных случаях могут быть привлечены 
средства из семейного бюджета студентов. Так в четырех федеральных землях ФРГ студенты могут осуществлять плату как за учебу, так и за организационные взносы. Еще существует определенный вид организаций, позволяющий осуществлять поддержку с выбором жилья, организованного питания и проведения досуга также за дополнительные средства из семейного бюджета.

В период с 2000 годов численность доли студентов в системе вузов по странам Европейского Союза среди всей обучающейся молодежи возросла до 15\%, для ФРГ она составляет около $13 \%$. Для Германии был также отмечен всплеск обучающихся в вузах в возрасте старше 30 -и лет, а это около $15 \%$ от общего кол-ва обучающихся в вузах. Это объясняется достаточно продолжительным средним образованием 13 лет и невозможностью определенному числу студентов из-за финансовых трудностей в отведенные сроки закончить данный образовательный уровень. В таких условиях студенты вынуждены оставлять достаточно длительный промежуток образовательной деятельности (4-6 лет) для того, чтобы поправить свое материальное положение и при определенного рода возможностях через некоторое время возвращаться к обучению [8].

Переход с национальной системы образования на болонскую привел как к ряду негативных, так и к ряду позитивных тенденций. К негативным можно отнести:

1. сокращение доли выпускников со степенью бакалавр по наукоемким специальностям: математика, естественные науки и информатика. В отдельных регионах падение составило около 50;

2. внедрены механизмы, контролирующие образовательную деятельность через компьютерно-экзаменационную модель тестирования освоенного материала, что уменьшает роль взаимодействия профессорско-преподавательского состава со студентами вуза;

3. снижение мобильности студентов. Ограниченные сроки освоения программ, разноплановость учебных дисциплин в рамках одной специальности не только по вузам ЕС, но 
и внутри ФРГ. Нелояльность системы в виде перезачетов, если студент, к примеру, прошел курс обучения за рубежом по тем или иным дисциплинам у других преподавателей по идентичным предметам и там получили зачетные оценки, то это не будет основанием для автоматического перезачета;

4. расширение влияния административного управления на деятельность вузов. До перехода на болонскую образовательную модель администрирование и научная деятельность были разделены в системе функционирования университетского образования, а должность ректора и декана ограничивалась 2-х летним сроком, но после нововведений влияние ректора как на административный, так и научный аппарат вуза было значительно расширено, а пребывание на посту ректора было определено 4-5 летним сроком пребывания, что нанесло урон на демократические и преемственные принципы функционирования вузов;

5. разрушение идеалов гуманитарных специальностей. Немецкая интеллектуальная элита утверждает, что болонский процесс исказил ценность гуманитарных знаний из-за сокращения программы до 4-х лет, а сама образовательная деятельность стала напоминать набор кредитов, по которым происходит процесс аттестации студента, в конечном итоге это стало приводить и к падению интереса у студентов к исследовательской деятельности.

Позитивную сторону болонского процесса можно выразить в следующий форме:

1. произошло увеличение доли числа иностранных студентов. Германия традиционно была интересна для иностранных студентов, интеграционные процессы внутри ЕС позволили стереть внутригосударственные границы в рамках Европейского Союза, что дало импульс свободного выбора места обучения, введение единой европейской валюты «евро» внесло ясность в стоимость обучения и проживания, а переход на образовательный процесс по болонской систе- 
ме ввел унификацию для общеевропейского пространства, что позволило привлекать студентов из стран восточной Европы (Украины, России и т.д.), а также азиатского и других регионов.

2. постоянная модернизация образовательных программ. Высокая степень сотрудничества между университетами в рамках болонской системы позволила расширить количество и качество образовательных дисциплин.

3. образовательная деятельность строится на модульной основе, что позволяет профессорско-преподавательскому составу и студентам организовывать более гибкую образовательную траекторию, наполняя различным, а главное актуальным, содержанием каждого модуля, что сказывается на современном подходе к системе вузовского обучения.

Правительство ФРГ всегда имеет четко выраженную позицию по образовательным инновациям, и она заключается в том, что необходимо позиционировать немецкую государственно-образовательную политику как ведущую среди индустриально-развитых держав для поддержания высоких международных рейтингов, характеризующих успешность ФРГ. Ввиду глобализации мировой экономики, а также демографических проблем (Таблица 1), связанных с отрицательной рождаемостью и быстрорастущего старения населения, которое выливается в нехватку трудовых ресурсов в сравнении с той же Французской Республикой. Правительство ФРГ пытается устранить эти проблемы с целью поддержания высокой индустриальной производительности через систему снижения бюрократических издержек для расширения инвестирования из-за рубежа в наукоемкие отрасли Германии, а также создания высокой степени роботизированности производственных секторов экономики.

Вопрос, затрагивающий образовательную систему высшего профессионального образования Французской Республики, кажется нам не менее интересным и требующим отдельно исследования. Французский шарм и огромная история этой великой европейской 
страны всегда позволяла занимать Франции первые строки в ежегодном кол-ве посещения туристами этого государства более 80 млн. человек, для сравнения доля туристов, посетивших ФРГ, составляет чуть менее 25 млн. чел. [7].

Современная образовательная политика Французской Республики строится на том, чтобы, в первую очередь, сохранить принципы преемственности и равноправия. Образовательная система во Франции характеризуется многослойностью, т.к. за годы длинного исторического пути накапливала лучшее и ценное, опираясь исключительно на свой многовековой опыт. А модель равных возможностей заложила возможность получить одинаково качественное образование как в мегаполисах, так и в удаленных от Парижа регионах.

Подход, заложенный Французскими идеологами, что французы должны любить свою национальную идентичность, нашел отражение и в системе образования. Франция относится к государствам, которые имеют свой национальный образовательный цикл, учебные степени и дипломы. Государственная поддержка образовательного сектора высшего образования настолько огромна, что характеризуется в его бесплатности как для резидентов, так и для иностранных студентов. Плата за образовательную деятельность в основном приходится на организацию места жительства, еду и т.д.

По завершении обучения по образовательной программе в школе, которое должно быть подтверждено наличием аттестата о среднем образовании, абитуриент может быть зачислен на ту или иную программу в тот или иной вуз с целью получения профессиональной специальности. Для нашего общего представления образовательная система высшего образования Франции труднопонимаема, т.к. разделена на 2-е категории: 1. Университеты; 2. Элитные вузы. В стране действует более 90 университетов и 3000 высших школ [12]. Система высшего образования Франции осуществляет образовательную деятельность в основном на французском языке, но существует множество программ и для англоязычных студентов, в основном они носят уровень магистерских и существуют на платной основе $[5 ; 6]$. 
Реализация болонского процесса привела к унификации образовательного пространства на Европейском Континенте. Так в 2002 году французское правительство выпустило декрет за номером № 2002-482 от 08.04.2002 г. «Об изменении архитектуры высшего образования Франции в связи с формированием Европейского пространства высшего образования», данный образовательный цикл был разделен на три уровня: Licence (эквивалент степени бакалавр в РФ), Master (магистратур), Doctorat (аспирантуа/докторантура).

Образовательный период степени Licence составляет 3 года и подразумевает набор 180 кредитов по системе ECTS, уровень Master подразумевает освоение программы в 2-х летний период со 120 кредитным набором ECTS и Doctorat 3 года с 180 кредитами ECTS [4].

Европейский Союз запустил мощную программу по обмену студентами «Erasmus Programme (EuRopean Community Action Scheme for the Mobility of University Students)», в которой Французская Peспублика принимает активное участие. Переход на болонскую систему позволил студентам из Франции быть более мобильными и при определенных обстоятельствах поехать учиться за рубеж при прохождении идентичной программы, даже если он закончил 1-ый или 2-ой курс в французском университете, студент может пройти семестровую или годичную программу в другом вузе Европы с получением перезачета по освоенным дисциплинам. А некоторые вузы Франции закрепили данную образовательную практику, сделав обязательным прохождение годовой образовательной программы за рубежом. По мнению интеллектуальной элиты Франции, данный подход полезен по двум причинам: 1-ая делает акцент на расширении знаний иностранного языка и познании культуры другого государства; 2-ая опирается на то, что студенты так более продуктивно перенимают зарубежный опыт как системы образования другого государства, так и их технического прогресса.

Кол-во иностранных студентов, приходящихся на эти две страны ЕС, очень близко (ФРГ около 21,8\% (чуть менее 260000 иностранных студентов) и Франции 19,8\% (более 236000 тыс.) в ми- 
ровом рейтинге около 10/10\%), по значению, без сомнения, они являются лидерами по экспорту образовательных услуг за рубеж. Без сомнения, мировым лидером является США, в этом государстве обучается более 590000 тыс. иностранных студентов [1].

Также для определения успешной государственно-образовательной политики используется практика составления внутригосударственных и международных рейтингов высших образовательных организаций того или иного государства. В каждом государстве национальное правительство любой страны с опаской ждет ежегодного опубликования данных об успешности их университетов в международно-сравнительном аспекте. Разработанная модель оценки рейтинга успешности университетского образования по странам, издаваемая вузом Шанхая, всегда вызывает бурную дискуссию среди руководства вузов и профессорско-преподавательского состава высших школ по всему миру, соглашаясь с позицией, что отобранные критерии не всегда определяют истинное положение успешности вузов в международном аспекте. Но ввиду того, что для будущих абитуриентов любые публикуемые данные будут носить информативный характер, преимущество будет отдано тем странам и вузам, которые стоят на высоких позициях рейтинга. Так публикуемые данные по системе Шанхайского университета, в который вошли 100 университетов по всему миру, сформировали рейтинг ведущих западных систем образования, в котором 50 университетов были из США, 10 из Соединенного Королевства, 5 университетов было из ФРГ и по 4 из Франции и Швеции. Особая позиция в формировании рейтинга приходится на количество публикаций, изданных в международно признанных журналах, что создает гонку в кол-ве публикуемых статей между мировыми вузами [10].

В условиях все более возрастающей конкуренции и желания отдельных государств быть не только региональными, но и мировыми лидерами по экспорту образовательных услуг, распространяя свою национальную идеологию, язык, культуру и т.д., это также позволяет отдельным государствам за счет иностранных студентов пополнять университетские, региональные и федеральные бюдже- 
ты. Основываясь на этих выводах, мы предлагаем использовать модель индекса развития образования, основанного на структуре идеолого-образовательной логистики, для определения успешности государственно-образовательной политики того или иного государства в международном аспекте.

Образовательно-национальные традиции, как и государственные приоритеты внутренней и внешней политики, у каждой страны свои. Модель идеолого-образовательной логистики (ИОЛ) в своей концепции ставит задачи по созданию максимально прозрачной системы, позволяющей дать однозначную характеристику успешности проводимых реформ в той или иной сфере, в частности и образовательной. ИОЛ в своей концепции предлагает использовать целый набор инструментов:

1. Внутреннее законодательство, а также ратифицированные международные договоры в сфере образовательной деятельности, влекущие передачу национальных полномочий на контроль наднациональных органов;

2. Культурно-историческая идентичность;

3. Экономико-социальные приоритеты;

4. Историко-педагогическая преемственность государства по сохранению собственных воспитательно-образовательных традиций с распространением их за рубеж.

5. Научно-исследовательское оснащение, позволяющее исследователям создавать наукоемкую продукцию;

6. Кол-во профессорско-преподавательского состава, цитируемого в международно-признанных научных изданиях;

7. Государственная поддержка исследовательской деятельности;

8. Развитость среды, ее финансовые возможности, а также заинтересованность правительства в воспитании интеллектуальной элиты государства.

Таким образом, доктриной идеолого-образовательной логистики в системе международно-сравнительного анализа государственно-образовательной политики (внутренней и внешней) между странами будет являться: 
1. Принятие парадигмы, определяющей расширение в использовании научно-исследовательских принципов ИОЛ;

2. Развитие диалоговых программ между государствами с целью создать общую модель, основанную на ИОЛ, по формированию прозрачной системы в оценке государственно-образовательной политики в сфере образования в международном аспекте;

3. Создание межправительственных и наднациональных органов по координированию прозрачности публикуемых данных об успехах в системе образования между государствами с целью недопущения подачи искаженных данных;

4. Создание и развитие межгосударственных программ с наднациональным регулированием образовательной деятельности на всех уровнях с целью более тесного сотрудничества по унифицированию законодательных проектов в сфере образования;

5. Развитие межнационального, межрелигиозного и межкультурного диалога на полях международных саммитов с привлечением интеллектуальной, политической и духовной элит с целью принятия общего коммюнике в сфере регулирования международной образовательной деятельности.

Применяя методологию идеолого-образовательной логистики (ИОЛ) в системе стратегического управления интеллектуальным капиталом в международно-сравнительном аспекте, мы прежде всего должны проанализировать понятийный аппарат ИОЛ: это теоретико-практическое направление в педагогической науке, выраженное в виде квалиметрического алгоритма, позволяющего целенаправленно оценивать как в дифференциальной, так и интегральной формах качество реализуемой государственно-образовательной политики по отдельно взятым государствам в определенные временные промежутки с характеристиками, основанными на принципах истинности и аргументированности.

С целью определения более или менее успешной государственно-образовательной политики в международном аспекте, мы передоложили использовать авторскую квалиметрическую модель, 
основанную на ИОЛ. Отмечая тот факт, что ИОЛ в своей работе использует только статистические данные, публикуемые авторитетными источниками, и исключает использование субъективных методов, таких как опрос, анкетирование, мнение экспертов и т.д., что, в свою очередь, позволяет получить эмпирические данные по тому или иному государству. Для формирования рейтингово-бальной системы нами была использована структурно-квалиметрическая модель, основанная на ИОЛ (Таблица 1, Модель 1, Формула 1).

Прежде чем рассматривать Францию и ФРГ в структурно-сравнительной оценке в международном аспекте, рассчитанной по методологии ИОЛ, хотелось бы уточнить несколько фактов. Для обзорного исследования нами были выбраны 49 государств от самых развитых стран западного мира до государств Африканского континента, находящихся к югу от Сахары. Проведенное исследование позволило получить следующие результаты (Таблица 3). Временной промежуток 2010 и 2014 годов был взят ввиду самого стабильного времени, отмеченного в международных отношениях (2008 г. мировой финансовый кризис, 2014 г. события на Украине). Для обзора состояния государственно-образовательной политики КСА нами были выбраны 20 самых успешных систем образования по странам. Государства СНГ не брались во внимание, т.к. этому будет посвящено отдельное исследование, исключением стала РФ, т.к. мы просто не могли исключить из данного исследования нашу национальную систему образования. Также отмечаем, что данное исследование носит ознакомительный характер, ввиду того, что главной целью является проверка способности ИОЛ давать квалиметрическую оценку тому или иному государству в международном аспекте, используя рабочую формулу расчета оценки государственно-образовательной политики. Хотелось бы отметить и тот факт, что использованная нами статистическая литература хоть и была взята из самых авторитетных источников (World Statistics Pocketbook, Democracy Index, BP Statistical Review of World Energy, Global-Peace-Index, Failed States Index, SIPRI Armaments, Disarmament and International Security, 
Transparency International Corruption Perceptions Index, freedom in the World, Freedom on the Net, Freedom of the press, Global terrorism index, Human Development Index, доклады ООН, ЮНЕСКО и многие другие), но она также может иметь и свои неточности.

Модель 1.

Перевод какого-либо результата в бальную систему
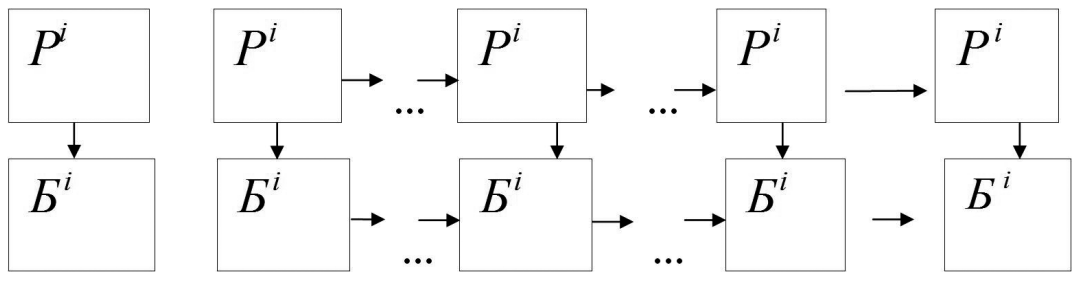

Примечание.

$P^{i}: P$ - это один из показателей государства; ${ }^{i}$ - любое исследуемое государство.

$Б^{i}: 5$ - количество баллов, полученных после тестирования по таблицам для исследуемого государства; ${ }^{i}$ - любое исследуемое государство.

Формула 1.

\section{Индекс развития образования}

$T_{2}=\frac{Y_{i}-Y_{\min }}{Y_{\max }-Y_{\min }}$

Примечания:

$x_{i}=\sum-$ по всем показателям в баллах по таблице 1 исследуемой страны.

$\min (\mathbf{Y})$ и $\max (\mathbf{Y})$ - это минимальное и максимальное значение показателей среди всех исследуемых государств по Таблице 1.

Индекс развития образования

\begin{tabular}{|c|c|c|c|c|c|c|c|c|c|c|c|}
\hline $\begin{array}{c}\text { Бал- } \\
\text { лы }\end{array}$ & $1 .^{1}$ & $2 .^{2}$ & $3 .^{3}$ & $4 .^{4}$ & $5 .^{5}$ & $6 .^{6}$ & $7 .^{7}$ & $8 .^{8}$ & 9. ${ }^{9}$ & $10 .^{10}$ & $11 .^{11}$ \\
\hline 1 & $>81$ & $>81$ & 62 & $>22$ & $19<$ & & 0,4 & 70 & 0,1 & 0,1 & 0,1 \\
\hline 2 & 82 & 82 & 64 & 24 & 18 & & 0,43 & 60 & 0,2 & 0,2 & 0,2 \\
\hline 3 & 83 & 83 & 66 & 26 & 17 & & 0,46 & 50 & 0,3 & 0,3 & 0,3 \\
\hline 4 & 84 & 84 & 68 & 28 & 16 & & 0,49 & 40 & 0,4 & 0,4 & 0,4 \\
\hline
\end{tabular}


Окончание табл. 2.

\begin{tabular}{|c|c|c|c|c|c|c|c|c|c|c|c|}
\hline 5 & 85 & 85 & 70 & 30 & 15 & Коммунитаризм & 0,52 & 35 & 0,5 & 0,5 & 0,5 \\
\hline 6 & 86 & 86 & 72 & 32 & 14 & Гуманизм & 0,55 & 30 & 0,6 & 0,6 & 0,6 \\
\hline 7 & 87 & 87 & 74 & 34 & 13 & $\begin{array}{l}\text { Марксизм- } \\
\text { ленинизм }\end{array}$ & 0,58 & 25 & 0,7 & 0,7 & 0,7 \\
\hline 8 & 88 & 88 & 76 & 36 & 12 & Коммунизм & 0,61 & 20 & 0,8 & 0,8 & 0,8 \\
\hline 9 & 89 & 89 & 78 & 38 & 11 & $\begin{array}{c}\text { Социал- } \\
\text { демократия }\end{array}$ & 0,64 & 18 & 0,9 & 0,9 & 0,9 \\
\hline 10 & 90 & 90 & 80 & 40 & 10 & $\begin{array}{c}\text { Мульти- } \\
\text { культурализм }\end{array}$ & 0,67 & 16 & 1 & 1 & 1 \\
\hline 11 & 91 & 91 & 82 & 42 & 9 & $\begin{array}{c}\text { Идеологический } \\
\text { и политический } \\
\text { плюрализм }\end{array}$ & 0,7 & 14 & 2 & 2 & 2 \\
\hline 12 & 92 & 92 & 84 & 44 & 8 & $\begin{array}{c}\text { Идеология } \\
\text { европеизма }\end{array}$ & 0,73 & 12 & 4 & 4 & 4 \\
\hline 13 & 93 & 93 & 86 & 46 & 7 & Глобализм & 0,76 & 10 & 6 & 6 & 6 \\
\hline 14 & 94 & 94 & 88 & 48 & 6 & Консерватизм & 0,79 & 8 & 8 & 8 & 8 \\
\hline 15 & 95 & 95 & 90 & 50 & 5 & Либерализм & 0,82 & 6 & 10 & 10 & 10 \\
\hline 16 & 96 & 96 & 92 & 52 & 4 & $\begin{array}{c}\text { Социалистическая } \\
\text { коммунистическая } \\
\text { идеология } \\
\end{array}$ & 0,85 & 5 & 12 & 12 & 12 \\
\hline 17 & 97 & 97 & 94 & 54 & 3 & $\begin{array}{c}\text { Религиозная } \\
\text { идеология (буддизм) }\end{array}$ & 0,88 & 4 & 14 & 14 & 14 \\
\hline 18 & 98 & 98 & 96 & 56 & 2 & $\begin{array}{c}\text { Религиозная } \\
\text { идеология } \\
\text { (Христианство) } \\
\end{array}$ & 0,91 & 3 & 16 & 16 & 16 \\
\hline 19 & 99 & 99 & 98 & 58 & 1 & $\begin{array}{c}\text { Религиозная } \\
\text { идеология (Ислам) }\end{array}$ & 0,94 & 2 & 20 & 20 & 20 \\
\hline 20 & 99,9 & $100<$ & 100 & $60<$ & 0,5 & $\begin{array}{c}\text { Вера } \\
\text { в исключительность }\end{array}$ & $>0,94$ & 1 & $20<$ & $20<$ & $20<$ \\
\hline
\end{tabular}

\footnotetext{
${ }^{1}$ Уровень грамотности от общего населения государства в процентах

${ }^{2}$ Совокупная доля обучающихся (начальная школа (на 100 жителей))

${ }^{3}$ Совокупная доля обучающихся (основное общее образование и среднее общее образование (на 100 жителей))

${ }^{4}$ Совокупная доля обучающихся (высшее (на 100 жителей)).

${ }^{5}$ Потребление алкоголя на душу населения

${ }^{6}$ Наличие государственной идеологии или религии

${ }^{7}$ Уровень человеческого потенциала

${ }^{8}$ Кол-во университетов, входящих в рейтинг топ-500 к населению в миллионах

$9 \%$ в мировом объеме публикаций

$10 \%$ в мировых ВРНИОКР

11 \% исследователей от мирового показателя
} 
Индекс развития образовательного потенциала

Таблица 3.

\begin{tabular}{|l|l|l|l|l|l|}
\hline Ранг & Государство & Баллы-2010 г. & Ранг & \multicolumn{1}{|c|}{ Государство } & Баллы-2014 г. \\
\hline 1 & США & 1 & 1 & США & 1 \\
\hline 2 & Япония & 0,9257 & 2 & Япония & 0,9034 \\
\hline 3 & Великобритания & 0,8685 & 3 & Великобритания & 0,875 \\
\hline 4 & Германия & 0,84 & 4 & Германия & 0,8409 \\
\hline 5 & Италия & 0,8342 & 5 & Италия & 0,8295 \\
\hline 6 & Франция & 0,8057 & 6 & Китай & 0,8125 \\
\hline 7 & Австралия & 0,8057 & 7 & Франция & 0,8068 \\
\hline 8 & Ю. Корея & 0,7771 & 8 & Ю. Корея & 0,7897 \\
\hline 9 & Китай & 0,7542 & 9 & Турция & 0,75 \\
\hline 10 & Турция & 0,7142 & 10 & Австралия & 0,7443 \\
\hline 11 & Израиль & 0,7085 & 11 & Сауд. Аравия & 0,7272 \\
\hline 12 & РФ & 0,6857 & 12 & Израиль & 0,7102 \\
\hline 13 & Норвегия & 0,68 & 13 & Норвегия & 0,6818 \\
\hline 14 & Бразилия & 0,6742 & 14 & РФ & 0,6761 \\
\hline 15 & Сауд. Аравия & 0,6571 & 15 & Сингапур & 0,6647 \\
\hline 16 & Сингапур & 0,6514 & 16 & Аргентина & 0,6420 \\
\hline 17 & Аргентина & 0,6285 & 17 & Бразилия & 0,6193 \\
\hline 18 & Финляндия & 0,6114 & 18 & Швейцария & 0,6136 \\
\hline 19 & Швейцария & 0,6 & 19 & Финляндия & 0,6136 \\
\hline 20 & Польша & 0,5657 & 20 & Польша & 0,5681 \\
\hline 21 & Чехия & 0,56 & 21 & Чехия & 0,5625 \\
\hline 22 & Мексика & 0,5085 & 22 & Иран & 0,5568 \\
\hline 23 & Тунис & 0,4742 & 23 & Оман & 0,5056 \\
\hline 24 & Таиланд & 0,4685 & 24 & Таиланд & 0,4772 \\
\hline 25 & Иордания & 0,4628 & 25 & Тунис & 0,4772 \\
\hline & & & & \\
\hline
\end{tabular}

Таким образом, подходя к выводам, хотелось бы отметить, что проведенное исследование позволило ранжировать государства, основываясь на методологии ИОЛ в оценке индекса развития образовательного потенциала, разместив ФРГ и Францию на характерно высоком уровне. Многие рейтинговые агентства также размещают эти государства на высоких позициях, следовательно, можно определить в предварительных выводах, что модель ИОЛ в той или иной степени может быть использована в структурной оценке определения образовательного потенциала того или иного 
государства. Возвращаясь к ФРГ и Франции и их государственно-образовательной политике, можно отчетливо разглядеть очень схожие взгляды правительств этих стран на образовательные системы, которым отводится центральное место в преобразовании государственных приоритетов, сохранения культурно-национальной идентичности поколений, а также расширения своего присутствия за пределами государственной границы. Глобализация человечества привела к тому, что государства находятся в постоянно тесном сотрудничестве между собой, а многие страны добровольно передают свои национальные интересы наднациональным органам (ЕС, ВТО, НАТО, ЕАЭС и многие др.), которые принимают за них внешнеполитический курс развития объедения со всеми вытекающими последствиями. Франция и Германия, будучи экономическими и политическими локомотивами ЕС, совместно переживают кризис перехода от их национальной системы образования к унифицированной общеевропейской с имеющимися как достоинствами, так и недостатками в развитии высшего национального образования. Как видно из проведенного исследования систем высшего образования как Франции, так и ФРГ, они сохраняют паритет между аккумулированием своих национальных традиций в образовательной сфере, сохраняя свою государственно-культурную идентичность, и соблюдают взятые на себя обязательства по унификации образовательного законодательства в рамках общеевропейского образования. Объединение стран в политико-экономический союз ЕС напрямую или косвенно повлиял на европеизацию образовательных систем, а тот факт, что Франция и Германия являются образовательными лидерами на международной арене по экспорту образовательных услуг за рубеж как в рамках ЕС, так и за пределы Европейского Объединения, можно охарактеризовать эти два европейских государства как соперники. Говорить о явном преимуществе кого-либо из этих государств не приходится, т.к. они очень близки по некоторым критериям (политико-экономические цели), но в тоже время они находятся на разных чашах весов по различным другим позициям (культурно-на- 
циональная идентичность). Но обе эти страны используют весь имеющийся у них арсенал инструментов в реализации политики мягкой силы, особенно используя рычаги системы высшего образования. Обобщая изложенный материал, прежде всего хотелось бы акцентировать внимание на том, что необходимо поддержать широкое внедрение принципов идеолого-образовательной логистики в сфере оценки успешности государственно-образовательной политики в международном аспекте. В качестве основного средства в реализации данного проекта мы предлагаем использовать организационно-управленческую модель функционально-содержательного инструментария, основанную на ИОЛ, имеющую стратегическое направление по созданию прозрачной рейтингово-бальной системы оценки образовательной деятельности того или иного государства.

\section{Список литературы}

1. Билибин Д.П. Системы набора иностранных студентов в классические университеты. Учеб. пособие / Д.П. Билибин, А.С. Голованов, В.А. Конник, Г.Г. Соколов. М.: РУДН, 2008. 382 с.

2. Большой юридический словарь / Под ред. А.Я. Сухарева. М.: ИНФРА-М, 2007. 858 с.

3. Заблоцкая О.А. Многоуровневая система университетского образования во Франции // Universum: психология и образование. 2014. №5-6 (6). С. 1-17.

4. Заблоцкая О.А. Специфика профессиональной лиценциатуры во Франции // Известия ЮФУ. Технические науки. Тематический выпуск «Педагогика и психология». 2011. № 10 (123). С. 97-102.

5. Крайсман Н.В. Система высшего образования во Франции: слабые стороны, парадоксы и задачи университетов / Н.В. Крайсман, Д.Д. Фушель // Современные проблемы науки и образования (электронный журнал). 2015. № 2-2.

6. Крайсман Н.В. Студенческая мобильность между университетами России и Франции в контексте мультикультурной образовательной системы // II международный форум по педагогическому образованию. 2016. С. 275-277. 
7. Манаков А.Г. Туристские регионы мира. География культурного наследия: Учебное пособие. Псков: ПГПУ, 2011. 320 с.

8. Семёнова Ю.И. Государственная инновационная политика Германии в сфере высшего образования в условиях формирования единого европейского образовательного пространства // Ученые записки. Электронный научный журнал Курского государственного университета, no. 3 (19), 2011. С. 120-128.

9. Шпаковская Л.Л. Политика высшего образования в Европе и России. СПб.: Норма, 2007. 328 с.

10.Эрвуэт Р. Система высшего образования Франции // Инновационные образовательные технологии. 2011. №2(26). С. 3-8.

11. CIA - The World Factbook [Электронный ресурс]. Режим доступа: https://www.cia.gov/index.html (дата обращения 30.08.2018 г.).

12. Laura R. International comparison of academic salaries, an exploratory study / R. Laura, G. Ivan, G. Phillip // Boston College Center for International Higher Education, 2008. P. 84.

\section{References}

1. Bilibin D.P., Golovanov A.S., Konnik V.A., Sokolov G.G. Sistemy nabora inostrannykh studentov $v$ klassicheskie universitety [Systems of recruitment of foreign students in classical universities]. M.: RUDN, 2008. 382 p.

2. Bol'shoy yuridicheskiy slovar' [Large legal dictionary]/ Ed. A. Ya. Sukharev. M.: INFRA-M, 2007. 858 p.

3. Zablotskaya O.A. Universum: psikhologiya i obrazovanie. 2014. №5-6 (6), pp. 1-17.

4. Zablotskaya O.A. Izvestiya YuFU. Tekhnicheskie nauki. Tematicheskiy vypusk «Pedagogika i psikhologiya». 2011. № 10 (123), pp. 97-102.

5. Kraysman N.V., Fushel' D.D. Sovremennye problemy nauki i obrazovaniya. 2015. № 2-2.

6. Kraysman N.V. II mezhdunarodnyy forum po pedagogicheskomu obrazovaniyu [II International Forum on Teacher Education]. 2016, pp. 275-277.

7. Manakov A.G. Turistskie regiony mira. Geografiya kul'turnogo naslediya [Tourist regions of the world. Cultural Heritage Geography]. Pskov: PGPU, 2011. 320 p. 
8. Semenova Yu.I. Uchenye zapiski. Elektronnyy nauchnyy zhurnal Kurskogo gosudarstvennogo universiteta, no. 3 (19), 2011. C. 120-128.

9. Shpakovskaya L.L. Politika vysshego obrazovaniya v Evrope i Rossii [Higher education policy in Europe and Russia]. SPb.: Norma, 2007. 328 p.

10. Ervuet R. Innovatsionnye obrazovatel'nye tekhnologii. 2011. №2(26), pp. 3-8.

11. CIA - The World Factbook. https://www.cia.gov/index.html

12. Laura R., Ivan G., Phillip G. International comparison of academic salaries, an exploratory study. Boston College Center for International Higher Education, 2008. P. 84.

\section{ДАННЫЕ ОБ АВТОРЕ}

Житнов Евгений Александрович, методист, кандидат педагогических наук

ГБОУ Школа «Свиблово»

ул. Седова, 4, корпус 1, г. Москва, 129323, Российская Федеращฺия

Zhitnovskij@yandex.ru

\section{DATA ABOUT THE AUTHOR}

Zhitnov Evgeny Aleksandrovich, Methodist, Candidate of Pedagogical Sciences

SBEI School «Sviblovo»

4/1, Sedova Str., Moscow, 129323, Russian Federation

Zhitnovskij@yandex.ru 